BABEL OF THE ATLANTIC 
THE MAX KADE RESEARCH INSTITUTE SERIES:

GERMANS BEYOND EUROPE

Series Editors

A. Gregg Roeber and Daniel Purdy

The Max Kade Research Institute Series is an outlet for scholarship that examines the history and culture of German-speaking communities in America and across the globe, from the early modern period to the start of the First World War. Books in this series examine the movements of the German-speaking diaspora as influenced by forces such as migration, colonization, war, research, religious missions, or trade. This series explores the historical and cultural depictions of the international networks that connect these communities, as well as linguistic relations between German and other languages within European global networks.

This series is a project of the Max Kade German-American Research Institute located on Penn State's campus. This Institute, co-directed by A. Gregg Roeber and Daniel Purdy, was founded in 1993 thanks to a grant from the Max Kade Foundation, New York. 


\section{Babel of the Atlantic}

EDITED BY BETHANY WIGGIN

The Pennsylvania State University Press University Park, Pennsylvania 
Library of Congress Cataloging-in-Publication Data

Names: Wiggin, Bethany, 1972- editor.

Title: Babel of the Atlantic / edited by Bethany Wiggin.

Description: University Park, Pennsylvania : The Pennsylvania State University Press, [2019] | Series: The Max Kade Research Institute series: Germans beyond Europe | Includes bibliographical references and index.

Summary: "A collection of essays examining colonial Philadelphia and its surroundings as a zone of cultural and linguistic interchange.

Documents everyday multilingualism and intercultural negotiations with special attention to themes of religion, education, race and the abolitionist movement, and material culture and architecture"Provided by publisher.

Identifiers: LCCN 2019001033 | ISBN 9780271083230 (cloth : alk. paper)

Subjects: LCSH: Multilingualism-Pennsylvania-History—18th century. | Multilingualism-Pennsylvania-PhiladelphiaHistory-18th century. | Multilingualism-Middle Atlantic States-History-18th century. Pennsylvania-ReligionHistory-18th century. |

Antislavery movements-Pennsylvania-History-18th century. Classification: LCC F152.B165 2019| DDC 306.44/60974811—dc23

LC record available at https://lccn.loc.gov/2019001033

Copyright (C) 2019 The Pennsylvania State University

All rights reserved

Printed in the United States of America

Published by The Pennsylvania State University Press,

University Park, PA 16802-1003

The Pennsylvania State University Press is a member of the Association of University Presses.

It is the policy of The Pennsylvania State University Press to use acid-free paper. Publications on uncoated stock satisfy the minimum requirements of American National Standard for Information Sciences-Permanence of Paper for Printed Library Material, ANSI Z39.48-1992. 